\title{
KARAKTERISTIK DAN POLA PENGOBATAN DIURETIK PADA PASIEN ASITES DI RAWAT INAP RUMAH SAKIT ISLAM SAMARINDA TAHUN PERIODE JANUARI-DESEMBER 2015
}

\author{
Beria Kundharindi*, Arsyik Ibrahim, Welinda Dyah Ayu \\ Fakultas Farmasi Universitas Mulawarman, Samarinda, Kalimantan Timur \\ email: beria1512@gmail.com
}

\begin{abstract}
ABSTRAK
Asites adalah akumulasi cairan di dalam rongga peritoneum yang merupakan salah satu komplikasi penting pada pasien sirosis hati. Penelitian ini meliputi karakteristik pasien (jenis kelamin, umur dan pekerjaan) serta pola pengobatan diuretik. Metode yang digunakan ialah retrospektif dengan teknik pengambilan data secara purposive sampling berdasarkan kriteria inklusi dan eksklusi didapatkan sebanyak 19 kasus. Hasil penelitian menunjukkan 15 kasus (79\%) pasien asites berjenis kelamin laki-laki sedangkan 4 kasus (21\%) berjenis kelamin perempuan. Berdasarkan umur diperoleh 2 kasus $(10,5 \%)$ umur $<40$ tahun, 4 kasus $(21 \%)$ umur 40-49 tahun, 11 kasus (58\%) umur 50-59 tahun dan 2 kasus $(10,5 \%)$ umur $>60$ tahun. Berdasarkan jenis pekerjaan diperoleh 9 kasus $(47 \%)$ pegawai swasta, 3 kasus (16\%) PNS, 3 kasus ibu rumah tangga, 2 kasus (11\%) pengganguran, 1 kasus (5\%) wiraswasta, 1 kasus $(5 \%)$ petani. Pola pengobatan pada pasien asites berdasarkan standar European Association or the Study of the Liver diperoleh 9\% kesesuaian penggunaan spironolakton dan $100 \%$ ketidaksesuaian penggunaan kombinasi spironolakton dan furosemid.
\end{abstract}

Kata Kunci : sirosis hati, spironolakton, furosemid

\begin{abstract}
Asccites is the accumulation of fluid in the peritoneum cavity which is one the important complication on chirrhosis patient. This research covers the characteristic of patient (kind of sex, age, and job) and the system o diuretic treatment. The used method is retrospective with data retrieval technique in purposive sampling based on the inclusion and exclusion get as many as 19 cases. This result showed that 15 cases (79\%) ascites male patient while 4 cases $(21 \%)$ ascites female patient. Based on age obtained 2 cases $(10,5 \%)$ aged $<40$ years, 4 cases (21\%) aged 40-49 years, 11 cases (58\%) aged 50-59 years and 2 cases $(10,5 \%)$ aged $>60$ years Based on job obtained 9 cases (47\%) self-employed, 3 cases (16\%) civil servant, 3 cases housewife, 2 cases (11\%) jobless, 1 cases (5\%) self-employed, 1 cases (5\%) farmer. Patterns of treatment in patients with ascites by European Association for the Study of the Liver obtained 9\% conformity the use of spironolactone and 100\% nonconformities using a combination of spironolactone and furosemide.
\end{abstract}

Keywords: liver chirrhosis, spironolactone, furosemide 


\section{PENDAHULUAN}

Menurut laporan rumah sakit umum pemerintah di Indonesia, rata-rata prevalensi sirosis hepatis adalah $3,5 \%$ dari seluruh pasien yang dirawat dibangsal penyakit dalam atau rata-rata 47,4\% dari seluruh pasien penyakit hati yang dirawat (Emilliana, 2013).

Hepatitis $\mathrm{C}$ dan alkohol adalah penyebab paling umum dari Sirosis dan berkontribusi terhadap kematian di Amerika Serikat dari 12 penyebab utama. Pada tahun 2000 lebih dari 25.000 kematian di Amerika Serikat akibat sirosis. Asites adalah komplikasi yang paling umum dari sirosis. Jika melihat selama 10 tahun, hampir $60 \%$ dari pasien sirosis menyebabkan terjadinya asites. Adanya asites berhubungan dengan 60-70\% tingkat kematian selama lima tahun (Tasneem etc, 2015).

Asites adalah timbunan cairan secara patologis dalam rongga peritoneum yang dapat disebabkan oleh berbagai penyakit terutama pada penyakit hati kronik atau sirosis hepatis. Kata asites berasal dari bahasa yunani askites dan askos yang berarti kantong atau perut.

Pembatasan garam merupakan cara utama untuk pengobatan asites yaitu dengan pemberian obat diuretik. Spironolakton merupakan diuretik pilihan pertama dalam terapi dan berfungsi menghalangi reabsorpsi garam/natrium pada tubulus distal ginjal. Kombinasi dua jenis diuretik dapat diberikan apabila monoterapi dengan spironolakton efeknya tidak memadai. Kombinasi yang terbaik adalah spironolakton dan furosemid yang bekerja pada tempat berbeda dalam nefron (Akil, 2012).

Dua penelitian telah dinilai yang merupakan pendekatan untuk terapi terbaik, baik antagonis aldosteron yang meningkat setiap 7 hari (100-400 mg / hari dalam $100 \mathrm{mg} / 7$ hari) dengan furosemide (40-160 mg / hari, di $40 \mathrm{mg} / 7$ hari).Tetapi pasien dengan asites pertama kali harus ditangani awalnya hanya dengan aldosteron antagonis (yaitu, spironolakton $100 \mathrm{mg} /$ hari) dari awal terapi dan meningkat secara bertahap setiap 7 hari sampai $400 \mathrm{mg}$ / hari (European Association for the Study of the Liver, 2010).

Penelitian ini bertujuan untuk mendapatkan data jumlah dan persentase penyakit asites dan mengetahui gambaran karakteristik pasien penyakit asites di Rumah Sakit Islam Samarinda. Selain itu, penelitian ini juga bertujuan untuk menganalisis kesesuaian pola pengobatan diuretik pada asites di rawat Inap Rumah Sakit Islam dengan guideline European Association for the Study of the Liver. Hal ini diharapkan dapat meningkatkan keberhasilan terapi.

\section{METODE PENELITIAN}

Penelitian ini menggunakan metode deskriptif evaluatif dan analisis data secara retrospektif dengan melihat status Rekam Medik Kesehatan (RMK) pasien asites di Instalasi Rawat Inap Rumah Sakit Islam Samarinda. Data yang diambil dari sejumlah pasien rawat inap yang didiagnosis menderita asites dengan periode januari sampai desember 2015. Jumlah keseluruhan sampel adalah 19 pasien dengan kriteria inklusi sebanyak 19 sampel yaitu pasien dengan diagnosa terakhir asites serta mempunyai data rekam medik yang lengkap.

\section{Prosedur}

Proses pengambilan data pada penelitian ini dilakukan dengan observasi umum rekam medik pasien asites periode 2015. Kemudian ditetapkan sampel yang ingin diteliti, selanjutnya dilakukan pencatatan atau pengumpulan data. Setelah itu data dianalisis dan dibuat tabulasi data. 
HASIL DAN PEMBASAHAN

\section{Karakteristik Pasien}

\section{Gambaran Pasien Asites Berdasarkan Jenis Kelamin}

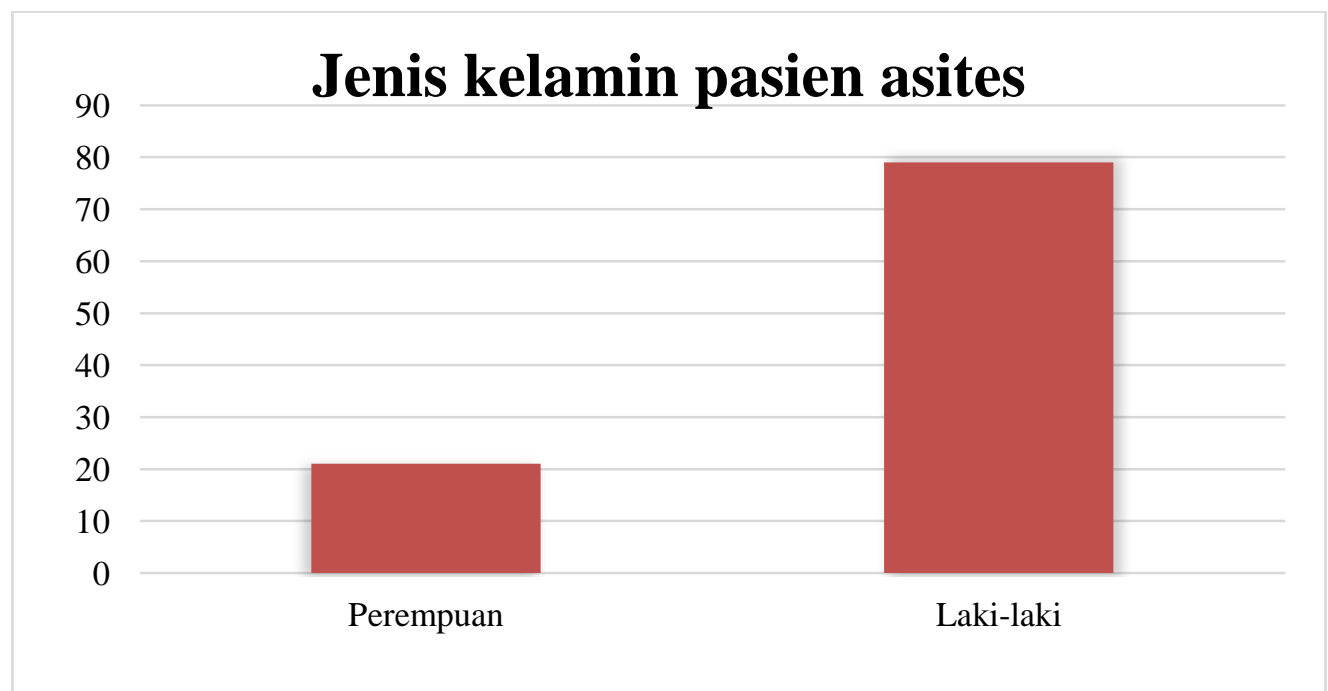

Grafik 1. Grafik Distribusi Jenis Kelamin Pasien Asites di Instalansi Rawat Inap RS Islam Samarinda periode 2015

Dari 19 kasus asites yang menjalani rawat inap di Rumah Sakit Islam Samarinda sebanyak $79 \%$ atau 15 pasien berjenis kelamin laki-laki dan $21 \%$ atau 4 pasien berjenis kelamin perempuan. Hal ini menunjukkan jumlah penderita asites laki-laki lebih besar dibandingkan perempuan.

Salah satu faktor penyebab terjadinya asites ialah konsumsi alkohol yang berlebihan. Menurut WHO, pada tahun 2000 sirosis dan diabetes ialah salah satu penyakit utama yang disebabkan alkohol dengan total kasus 4555. Bedasarkan penelitian yang dilakukan Suhardi tahun 2011, Prevalensi penduduk umur 15 tahun ke atas yang minum alkohol pada perempuan relatif rendah dan pada laki-laki jauh lebih dominan di semua provinsi Indonesia.

Selain itu faktor penyebab terjadinya asites ialah virus hepatitis. Menurut Baig, menunjukkan laki-laki lebih beresiko terkena hepatitis dibandingkan perempuan yaitu 7,1 : 1. Diamati bahwa varian reseptor estrogen (ER) yang dinyatakan lebih banyak pada pasien laki-laki dibandingkan pada pasien perempuan. Hal ini menyebabkan hilangnya respon estrogen sehingga membuat penyakit sirosis terjadi terutama pada pria dan wanita pasca menopause, dengan pengecualian dari penyakit autoimun hati. Dalam penelitian terbaru, Corrao dan rekannya (1998) menemukan bahwa 98,1 persen dari kasus sirosis pada pria tetapi hanya 67,0 persen kasus pada wanita yang dapat dikaitkan dengan konsumsi alkohol, hepatitis C, dan hepatitis B. Hal ini menunjukkan laki-laki lebih mudah beresiko terkena asites maupun gangguan fungsi hati lainnya. 


\section{Gambaran Pasien Asites Berdasarkan Umur}

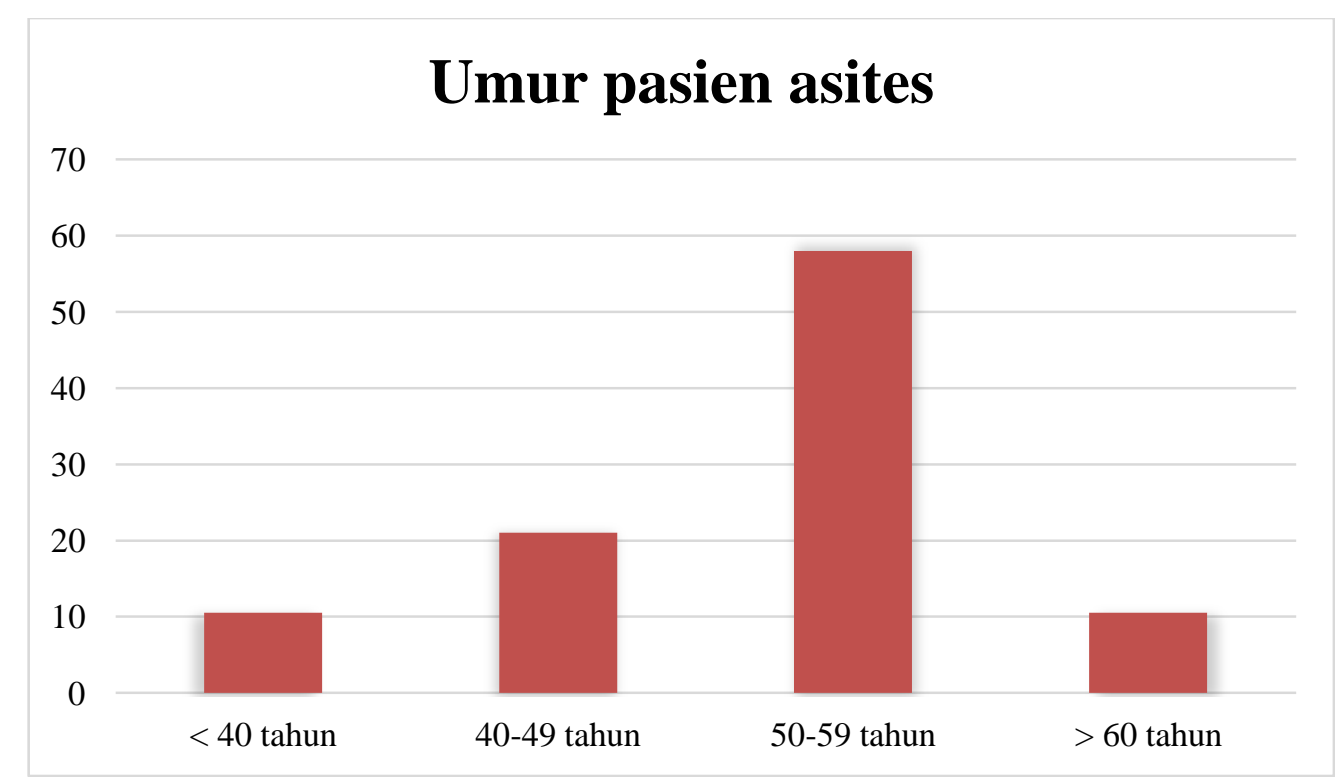

Grafik 2. Grafik Distribusi Umur Pasien Asites di Instalansi Rawat Inap RS Islam Samarinda periode 2015

Grafik 2 menunjukkan persentase pasien asites berdasarkan umur diketahui jumlah pasien yang berumur 50-59 tahun menunjukkan persentase terbesar yaitu 58\% (11 pasien), umur 40-49 tahun sebesar 21\% (4 pasien), umur $<40$ tahun sebesar 10,5\% (2 pasien) dan umur $>60$ tahun sebesar 10,5\% (2 pasien). Sirosis membutuhkan waktu untuk berkembang, kerusakan hati terjadi karena alkohol yang menumpuk selama beberapa tahun sehingga hati mulai mengalami kegagalan fungsi.

Menurut Robert dan rekannya, dalam kasus penyakit kronis, termasuk sirosis hati, tingkat kematian tampak lebih tinggi untuk populasi yang lebih tua daripada populasi yang lebih muda. Angka kematian Sirosis sangat rendah di kalangan muda tapi meningkat pesat di usia pertengahan, mencapai puncak 31,1 per 100.000 di antara orang yang berusia 75 sampai 84. Oleh karena itu peningkatan angka kematian sirosis pada usia pertengahan, berkontribusi untuk total kematian sirosi mencapai puncak pada kelompok 45-54 usia.

\section{Gambaran Pasien Asites Berdasarkan Jenis Pekerjaan}

Grafik 3 menunjukkan persentase pasien asites berdasarkan jenis pekerjaan diketahui jumlah pasien yang bekerja sebagai pegawai swasta menunjukkan persentase terbesar yaitu 47\% (9 pasien), sebagai PNS sebesar 16\% (3 pasien), sebagai ibu rumah tangga sebesar $16 \%$ (3 pasien), sebagai pengangguran sebesar $11 \%$ ( 2 pasien), sebagai wiraswata sebesar $5 \%$ (1 pasien) dan petani sebesar 5\% (1 pasien). WHO (2012), mengemukakan penderita hepatitis B jenis yang memiliki faktor resiko tinggi ialah pekerjaan dengan kontak langsung dengan darah yaitu petugas medis. Dari data yang diambil tidak tercatat jenis pekerjaan yang berhubungan dengan medis ataupun tidak. Tetapi pegawai swasta dan pegawai negeri sipil memungkinkan merupakan petugas medis. 


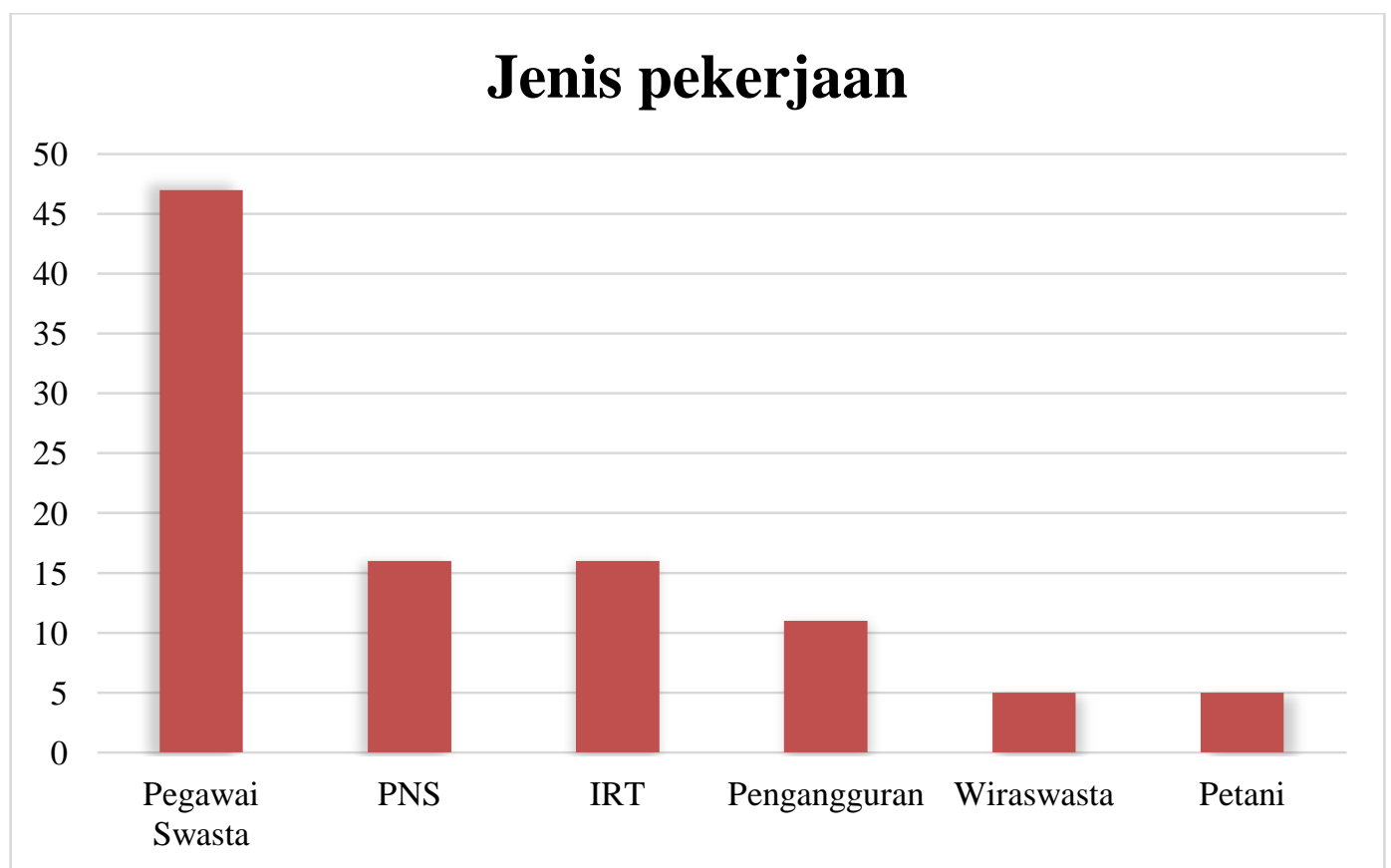

Grafik 3. Grafik Distribusi Jenis Pekerjaan Pasien Asites di Instalansi Rawat Inap RS Islam Samarinda periode 2015

\section{Pola Pengobatan Diuretik Pasien Asites}

Pasien asites diberikan terapi pembatasan garam yaitu dengan pemberian diuretik. Terapi diuretik diberikan secara tunggal maupun kombinasi. Hipokalemia dapat terjadi jika pasien diobati dengan diuretik loop saja. Hiperkalemia dapat berkembang sebagai hasil dari pengobatan dengan antagonis aldosteron atau diuretik hemat kalium lainnya, terutama pada pasien dengan gangguan ginjal. Hiponatremia adalah komplikasi lain yang sering terapi diuretik. Tingkat hiponatremia di mana diuretik harus dihentikan masih diperdebatkan. Namun, sebagian besar ahli setuju bahwa diuretik harus dihentikan sementara pada pasien yang serum natrium menurun hingga kurang dari 120-125 mmol / L. Ginekomastia adalah umum dengan penggunaan antagonis aldosteron, tetapi tidak biasanya membutuhkan penghentian pengobatan. Akhirnya, diuretik dapat menyebabkan kram otot. Jika kram yang parah, dosis diuretik harus dikurangi atau dihentikan dan albumin infus bisa meringankan gejala. Sehingga pasien dengan terapi diuretik tunggal maupun kombinasi harus sering dilakukan pengukuran kreatinin serum, natrium, dan konsentrasi potassium.

Hasil penelitian menunjukkan dari 19 kasus didapat 4 kasus (21\%) diberi terapi spironolakton , 8 kasus (42\%) diberi terapi spironolakton dan furosemid dan 7 kasus (37\%) tidak diberi terapi diuretik. Bedasarkan European Association for the Study of the Liver (2010), pada pasien asites yang terkena pertama kali diberikan dengan aldosteron antagonis (yaitu, spironolakton $100 \mathrm{mg}$ / hari) dari awal terapi dan meningkat secara bertahap setiap 7 hari sampai $400 \mathrm{mg} / \mathrm{hari}$. Hal ini disebabkan karena antagonis aldosteron lebih efektif daripada diuretik loop dalam penatalaksanaan asites dan merupakan diuretik pilihan. Aldosteron merangsang reabsorpsi natrium pada ginjal dengan meningkatkan baik permeabilitas membran luminal sel utama natrium dan aktivitas pompa $\mathrm{Na} / \mathrm{K}$ ATPase di membran basolateral.

Hasil penelitian menunjukkan 11 kasus merupakan pasien asites pertama sehingga diberikan terapi tunggal spironolakton. Dari 11 kasus yang seharusnya diberikan terapi 
spironolakton didapat 4 pasien tidak diberikan terapi diuretik, 2 pasien diberikan diuretik dan 5 pasien diberikan terapi kombinasi diuretik. Hal ini disebabkan beberapa pertimbangan dokter terhadap kondisi pasien. Pasien tidak diberikan terapi diuretik disebabkan kadar albumin yang normal atau tidak terlalu kecil sehingga diberikan terapi pembatasan garam berupa diet garam dan vitamin maupun suplemen hati. Menurut Aberg dan rekannya (2008), vitamin maupun suplemen hati banyak mengandung potasium sehingga bila diberikan dapat menimbulkan hiperkalemia. Selain itu kondisi pasien dengan infeksi bakteri ditandainya meningkatnya jumlah sel darah putih sehingga lebih diberikan terapi antibiotik. Pasien yang diberi terapi kombinasi disebabkan kadar albumin yang jauh dibawah normal (3,5-5,5 gr/dl). Menghindari terjadinya hipoalbumin sehingga langsung diberikan terapi kombinasi. Penurunan dosis diberikan untuk menghindari terjadinya dehidrasi. Obat Spironolakton yang tersedia dalam bentuk sediaan tablet dengan kandungan spironolakton sebesar $25 \mathrm{mg}$ bila berdasarkan guideline dosis spironolakton untuk terapi asites ialah $100 \mathrm{mg}$ sehingga harus meminum obat tersebut $4 \times 1$ hari. Maka dari itu dilakukan penurunan dosis untuk mengurangi ketidakpatuhan pasien dan efek samping seperti mual, muntah, diare maupun gastritis. Bila dibandingkan dengan guideline diperoleh kesesuaian penggunaan spironolakton ialah $9 \%$

Pemberian terapi kombinasi diuretik diberikan jika terapi diuretik spironolakton tidak berhasil. Terapi kombinasi yang terbaik ialah antagonis aldosteron yang meningkat setiap 7 hari (100-400 mg / hari dengan $100 \mathrm{mg} / 7$ hari) dengan furosemide (40-160 mg / hari, dengan $40 \mathrm{mg} / 7$ hari). Aldosteron merangsang reabsorpsi natrium pada ginjal dengan meningkatkan baik permeabilitas membran luminal sel utama natrium dan aktivitas pompa $\mathrm{Na} / \mathrm{K}$ ATPase di membran basolateral. Furosemid secara selektif menghambat reabsorpsi $\mathrm{NaCl}$ di cabang asenden tebal. Hasil penelitian menunjukkan 9 kasus yang seharusnya diberikan terapi spironolakton dan furosemide didapat 3 pasien diberikan terapi spironolakton, 3 pasien diberikan terapi spironolakton dan furosemid dan 1 pasien tidak diberikan terapi diuretik. Terapi diuretik tidak diberikan atau diberikan terapi tunggal disebabkan pasien dengan riwayat asites menunjukkan kadar albumin normal atau tidak terlalu kecil. Selain itu pasien asites dengan komplikasi hipertensi diberikan obat antihipertensi seperti propranolol maupu golongan angiotensin reseptor bloker sehingga diberikan terapi tunggal atau penurunan dosis untuk menghidari hipotensi. Pasien dengan riwayat diabetes mellitus tidak diberikan furosemide atau dilakukan penurunan obat furosemid. Berdasarkan beberapa penelitiaan, pemberian diuretik menimbulkan efek samping dysglycaemia (peningkatan gula darah) atau hyperglycaemia dan dalam jangka panjang dapat menyebabkan new-onset diabetes. Selain itu untuk menghidari dehidrasi dan ketidakseimbangan elektrolit dilakukan penurunan dosis.

Obat Spironolakton yang tersedia dalam bentuk sediaan tablet dengan kandungan spironolakton sebesar $25 \mathrm{mg}$. Obat furosemid tersedia dalam bentuk sedian injeksi dengan kandungan furosemid sebesar $20 \mathrm{mg}$ dan bentuk sedian tablet dengan kandungan furosemid sebesar $40 \mathrm{mg}$. Bila berdasarkan guideline dosis spironolakton untuk terapi asites ialah $100 \mathrm{mg}$ dan dosis furosemid ialah $40 \mathrm{mg}$ sehingga harus meminum obat spironolakton 4x1 hari dan furosemid 1x1 hari. Maka dari itu dilakukan penurunan dosis untuk mengurangi ketidakpatuhan pasien dan efek samping seperti mual, muntah, diare maupun gastritis. Bila dibandingkan dengan guideline diperoleh ketidaksesuaian penggunaan spironolakton dan furosemid ialah $100 \%$

\section{KESIMPULAN}

Bedasarkan penelitian yang dilakukan menunjukkan bahwa laki-laki lebih banyak terdiagnosis asites dibandingkan perempuan. Berdasarkan umur diperoleh umur 50-59 tahun lebih banyak terdiagnosis asites. Berdasarkan jenis pekerjaan diperoleh pegawai 
swasta lebih banyak terdiagnosis asites. Pola pengobatan pada pasien asites berdasarkan standar European Association or the Study of the Liver diperoleh 9\% kesesuaian penggunaan spironolakton dan $100 \%$ ketidaksesuaian penggunaan kombinasi spironolakton dan furosemid.

\section{DAFTAR PUSTAKA}

1. Aberg, Judith, A., etc. 2007. Drug Information Handbook ed 17. Lexi-comp. Hudson.

2. Akil, A. M. 2012.Buku Ajar Ilmu Penyakit Hati. CV Sagung Seto. Jakarta.

3. Baig, Saeeda. 2009. Gender Disparity in Infections of Hepatitis B Virus. Journal of the College of Physicians and Surgeons Pakistan, 19 (9): 598-600.

4. Emiliana, W. 2013. Sirosis Hepatis Child Pugh Class Dengan Komplikasi asites grade III dan Hiponatremi: Medula, 1(5): 51-57.

5. European Association for the Study of the Liver. 2010. EASL clinical practice guidelines on the management of ascites, spontaneous bacterial peritonitis, and hepatorenal syndrome in cirrhosis. Journal of Hepatology 2010 vol. 53. Hal : 397-417.

6. Mann, Robert E., Smart, Reginald G dan Govoni, Richard. 2004. The Epidemiology of Alcoholic Liver Disease. National Institute on Alcohol Abuse and Alcoholism, 27(3); 209-219.

7. Obot, Isidore S. dan Room, Robin. 2005. Alcohol, Gender and Drinking Problems Perspectives from Low and Middle Income Countries. World Health Organization Press. Geneva.

8. Schulte, Marya T., Ramo, Danielle., dan Brown, Sandra A. 2009. Gender Differences in Factors Influencing Alcohol Use and Drinking Progression Among Adolescents. Clin Psychol Rev, 29(6): 535-547.

9. Suhardi. 2011. Preferensi Peminum alcohol Di Indonesia Menurut Riskesdas 2007. Bul. Penelit. Kesehat, 39(4): $154-164$.

10. Taseneem, H., Shahbaz, H. dan Sherazi, B, A. 2015. Pharmacoepidemiology of ascites and associated complications in hospitalized patients: descriptive observational study. International Current Pharmaceutical Journal, 4(2): 343-346. 